\title{
Design of industrial corporate structure: development of an algorithm for selecting enterprises in a corporate governance group
}

Irina Omelchenko, Mikhail Zakharov, and Dmitry Lyakhovich*

Bauman Moscow State Technical University, Department of Industrial Logistics, 105005 Moscow, Russia

\begin{abstract}
The article is developed and presented an algorithm for selecting enterprises in a corporate governance group when designing of industrial corporate structures, the practical implementation of which will improve the efficiency of organizational decisions by their management. The article is addressed to specialists in the field of theory and practice of production organization.

Keywords: industry, enterprise, corporation, structure, supply, production, sales, control, algorithm.
\end{abstract}

\section{Introduction}

The process of selecting enterprises - participants of the corporate system in the corporate governance group in the design of industrial corporate structures includes three main steps [1-5]:

1) formation of the selection groups of enterprises - participants of the corporate system for each functional areas of the industrial corporate structures [1,2];

2) determination of all possible sets of enterprises - participants of the corporate system from the conditions for the implementation of supply and production and marketing constraints $[1,3,4]$;

3) choice of the optimal set of the enterprises - participants of the corporate system according to the criterion of minimum production and logistics costs of the industrial corporate structures $[1,4,5]$.

\section{Results}

The algorithm for selecting enterprises - participants of the corporate system in the corporate governance group in the design of the industrial corporate structures includes seven steps.

Step 1. Formation of a set of the enterprises - participants of the corporate system for the selection.

Step 2. Formation of a matrix of the relationships between organizations and/or enterprises.

Step 3. Development of the supply system and supply and marketing constraints. 
Step 4. Development of the objective function of the minimum production and logistics costs of the industrial corporate structures, solving the optimization problem of linear programming.

Step 5. Analysis of selected enterprises - participants of the corporate system.

Step 6. Adjusting the composition of the selection group of enterprises or changing their structure.

Step 7. Adoption of organizational decisions on the selection enterprises - participants of the corporate system in the corporate governance group in the design of the industrial corporate structures.

In the general case, the industrial corporate structures can be subdivided into functional areas, including supply, production, and marketing enterprises, transport support organizations, and a number of groups of other auxiliary organizations and/or enterprises [57].

Let us denote $E_{i j}$ is an enterprise belonging to a group of enterprises - participants in the corporate system from which recruitment will be carried out for the $i$-th functional area of the industrial corporate structures. The index $j$ varies in the range $1, \ldots, N_{i}$, where $N_{i}$ is the number of enterprises included in the selection group for the $i$-th functional area of the industrial corporate structures.

At steps 1, 2 of the algorithm for selecting enterprises - participants of the corporate system into the corporate governance group, when designing the industrial corporate structures based on the results of expert analysis, selection groups $E_{i}$ and a matrix of interconnections of organizations and/or enterprises $E_{i j}$, reflecting the possibility of joint entry of enterprises into the industrial corporate structures are formed and the mandatory presence of a particular organization and/or enterprise in the corporate system.

At step 3 of the algorithm for selecting enterprises - participants of the corporate system into the corporate governance group during the design of the industrial corporate structures, a system of supply and production and marketing restrictions is developed $[6,8,9]$, which is based on data from marketing research on market needs corresponding to the volume of production $S$, information on production capacities of the enterprises of selection groups $M_{i j}$, as well as information on production needs for raw materials, materials and components $R$, transport support services $T$ and marketing organizations and/or enterprises $L$.

At steps 4-7 of the algorithm for selecting enterprises - participants in the corporate system for the corporate governance group, when designing the industrial corporate structures, the target function of the minimum of production and logistics costs of the industrial corporate structures is developed $[10,11]$. The source data are the values of the average total costs $C_{i j}$ for each enterprise and/or organization with a full load of production capacities of the enterprises $M_{i j}$.

The mathematical formulation of the problem, including the objective function and the constraint system, has the following form:

$$
\begin{gathered}
\sum_{i=1}^{4} \sum_{j=1}^{N_{i}} C_{i j} x_{i j} \rightarrow \min , \\
\sum_{j=1}^{N_{1}} x_{1 j}=R, \sum_{j=1}^{N_{2}} x_{2 j}=S, \\
\sum_{j=1}^{N_{3}} x_{3 j}=L, \sum_{j=1}^{N_{4}} x_{4 j}=T, \\
x_{i j} \leq M_{i j}, x_{i j} \geq 0,
\end{gathered}
$$

where $x_{i j}$ is the volume of production $E_{i j}$ required from the enterprise. 
The values $x_{i j}$ corresponding to the minimum of the objective function are calculated according to the algorithm for solving the optimization problem of linear programming [12]. If $x_{i j}=0$ then this means that the enterprise is not included in the membership of the industrial corporate structures.

The results of the decision are analyzed for compliance with the matrix of interconnections of organizations and/or enterprises. Then, you can adjust the resulting solution or the selected group of the enterprises - participants of the corporate system to the corporate governance group when designing the industrial corporate structures and repeat the optimization decision linear programming tasks.

\section{Conclusion}

The developed algorithm for selecting enterprises - participants of the corporate system into the corporate governance group in the design of the industrial corporate structures is characterized by the fact that its formation is based on knowledge of resource connections.

The use of the algorithm allows you to simulate new or adjust the structures of existing organizations and/or enterprises, and the algorithm can be a tool for the adoption of organizational decisions by the industrial corporate structure's management. It should be noted that although some of its stages contain elements of subjective expert analysis, the results accuracy applied corresponds to the accuracy and degree of raw data uncertainty.

\section{References}

1. M.N. Zakharov, I.N. Omelchenko, A.S. Sarkisov, Situations of engineering and economic analysis (BMSTU Publ., Moscow, 2014)

2. L.K. Glinenko, E.V. Luzhko, Developing organisational management structures (NoraDruk, Kyiv, 2005)

3. A.A. Kolobov, A.I. Orlov, Integrated production and corporate structures design (BMSTU Publ., Moscow, 2006)

4. V.A. Pavlov, System dynamics of the enterprise (BMSTU Publ., Moscow, 2019)

5. C. Skowronek, Z. Sarjusz-Wolski, Logistyka w przedsiebiorstwie (PWE, Warszawa, 2016)

6. B.F. Wittek, Strategische Unternehmensführung bei Diversifikation (Walter de Gruyter $\mathrm{GmbH} \& \mathrm{Co}$ KG, Berlin, 2019)

7. K.Yu. Belonosov, Z.S. Terentieva, D.G. Lyakhovich, Problems of management theory and practice, 3-4, 63-68 (2019)

8. M.N. Zakharov, E.N. Fedorova, Proceedings of Higher Educational Institutions. Machine Building, 5, 65-70 (2005)

9. D.G. Lyakhovich, Proceedings of Higher Educational Institutions. Machine Building, 10, 73-81 (2006)

10. I.A. Goryacheva, Bulletin of the MSRU. Economics, 2, 47-53 (2015)

11. N.P. Belozertseva, A.V. Loksha, N.I. Petrova, ASR: Economics and Management, 4, 5053 (2017)

12. K.H. Borgwardt, The simplex method: a probabilistic analysis (Springer Verlag, Berlin, 1987) 